\title{
Usage of the Intemational Standards for the Process of Methodological Acts and Software of the Records Management
}

\author{
기록관리 방법론 법제화와 소프트웨어 개발을 위한 국제표준의 활용 \\ P. Bolortuya**
}

\begin{abstract}
$<$ ABSTRACT $>$
Since 2008, the General Archives Authority of Mongolia introduced management standards on international records, such as ISO 15489. GAAM translated the international standards and have trained government records managers with such standards. These international records management standards are also incorporated into the Mongolian records legislations and records management guidance. Complying with the standards are also the requirements for designing records management software in Mongolia.
\end{abstract}

Keywords: records management, GAAM, Mongolia, international records management standards, ISO 15489

$$
\text { 〈초 록〉 }
$$

2008년 이후 몽골에서는 정부기록관리를 현대화하기 위해 GAAM(몽골국가기록원)이 ISO 15489 등과 같은 국제기록관리표준을 도입하였다. GAAM은 국제표준을 번역하여 기록관리자에게 교육하고 각 정부기관 의 기록관리에 적용하는 등 기록관리 분야에 적극 활용하고 있다. 나아가 각종 국제기록관리표준을 몽골정부의 법제화와 정책화를 통해 반영하려는 노력을 기울이고 있다. 기록관리국제표준은 전자기록을 관리하기 위해 공공 분야뿐 아니라 민간 분야에서도 기록관리시스템 소프트웨어의 개발에 활용되고 있다. 몽골에서 새로 개발되고 있는 기록관리 소프트웨어의 기능 요건은 기록관리표준을 준수하도록 요구하고 있다.

주제어: 몽골기록관리, GAAM, 국제기록관리표준, 기록관리소프트웨어 기능 요건, ISO 15489

* 이 논문은 The 1st Korean-Mongolian International Conference on Archives(July 16, 2012), "Archives Management and Archival Studies in Mongolia and Korea: Trends and Prospects"에서 발표한 글임. ** Senior Officer, Information Technology Division of General Archival Authority of Mongolia - 접수일: 2013년 3월 22일 - 최초심사일: 2013년 3월 26일 - 게재확정일: 2013년 4월 20일 
ISO 15489 "Information and Documentation-Records Management”, used worldwide since 2001, was issued by the International Standardization Organization in the main purpose to achieve modern records management activities in various sectors of world countries to a level as to the technologically advanced century itself.

Main reason in implementing the standard follows such as any unit and manager of the world's organization must be responsible in leaving the organizational history with integrity and accuracy while maintaining responsible involvement when using those database; therefore organizational support is vital to the legislative environment of the document records operations, in clarifying the target level, in assigning equal role and responsibility to each and every individual involved, in establishing current demand of digital records such as, transferring, storing, using, disposing with the residing advantage of ability both in textual and digital records management.

Observing today's approach, in any organization's records creating activity the managers are mostly in charge of the main process related to records management. On the other hand, when all organizations such as governmental and non-governmental agencies hosting international standards on their operational activities, decentralizes the document recordings through prearranged features of the standard, which allows the whole organization including all of its managers and administrative levels where the documentation is generated as records tool. In other words, if document generation is possible then it automatically becomes a part of document recording process. In short the advantage of the standard relies in role and responsibility in bearing method that is facilitated within the standard.

In Mongolia, General Archival Authority (GAA), who has the full power to implement government policy in archive and records management sectors, in 2008, have realized the need of translated records management standards in both governmental and non-governmental organizations, reminded, suggested and organized number of training programs of distinct levels to managers who is in charge of records management. Including: GAA's training center syllabus, organizational records management according to plan, archive that grants professional ID for archive managers, gave lectures at basic records management and advanced IT courses on methods of implementing the standard throughout the organization.

It is understood that the recordings in governmental agencies shall be executed following the international records standards, however, the reality of understanding the importance of records and archives in Mongolian society proven to be non satisfactory and the managers assigned to the subject lacks social and organizational status to influence at the organizational level and the society, this calls for several obstacles to count.

Although keeping records seems to us that it is just the right job for the records keeper, manager, 
it serves much importance, accuracy and responsibility in leaving administrative level documentation recordings forever. Inculcation of the importance of the records is the top priority of the state administrative units conducting records management and archive.

In order to develop the current standards, we are facing a great demand to implement the international records management standards.

Therefore, first step in implementing complete set of records management standards is to establish the right legislative principle on administering both textual and software based records, on country level by updating all the current records management policies throughout units and departments, with unified standards and in providing governmental and non-governmental institutions with aligned software systems.

In the past 3-4 years, in order to engrain the international records management standards to various organizations of the country, General Archival Authority have been updating current and drafting new methodologies, policies, working in cooperation with state administrative agencies and private companies in the electronic environment, legislative archive, formulating software systems to support records management, implementing, guidance, servicing necessary extensions and development, specialty training and providing methodologies management. Including the following:

\section{Legislative Framework}

The Electronic Signature Act was initiated in, however, have no real progress in any sector in Mongolia.

\section{Methodological Framework}

\section{Records Management Guidance}

Previously were pursued lawmaking documents followed textual based records management and its arrangement. In 2008, the records management international standards were adopted and 2009 newly validated "Records management principal guidance" included the explicit guidance on managing the electronically established, transferred and saved documents records.

\section{Software Framing}

Automation of Records management offers lessens state owned organizations' workload, which runs on the recordings of official documents, time and cost utilization and acquiring of necessary information in a timely manner and many other benefits that are suitable to the society. Therefore, more governmental and non-governmental agencies have been using the Records management software 
systems since 2009 .

Across Mongolia central state administrative agencies have implementing the Records management software systems and most of the current software systems are written independently while some are being used as a separate module to e-office software. Even though governmental and non-governmental agencies are developing various software systems on records management, we place the following the requirements;

Records Managements Software System requirements:

- Archive and records management shall followed the legislative and professional guidelines

- Expediting document search and usage

- All the functions covered

- Satisfactory Information security and confidentiality

- Must be user friendly, other common and specific requirements

"National Campaign in Conducting Information Technology in State Archives and Records management" was approved by the $64^{\text {th }}$ State resolution of Mongolia.

The project supports the automation of organizational records management system or e-management, exchange of information and documents, transferring, saving and copying of records in easy proper way, which are suitable within information technology environment possibilities, while complying informational technology in organizational and state archival operations which will enable the prompt usage of information stored in the national archival holdings and improved preservation of the original documents. Achievements of this project are the records management and archival software systems conduct.

In Mongolia, "Electronic Mongolia project in 2005", "National project in Conveying Information Technology in State Archives and Records management" in 2006, "Information and Documentationrecords management" ISO 15489, International Standard in 2008, "Electronic Documentation Transfer International Standard" ISO 17933:2000 MNS ISO 17933:2008 in 2008, "National Campaign to promote Information Security project" 2010 and Electronic Signature Legislation in 2012, are followed by legislative documents managing all the activities such as e-record management, exchanging, transferring and saving conducting follows developing suitable policies, guidance and requirements.

In conclusion, the foundation of taking the records management activities into the international level has been successfully started and in next we can expect to see the results of development of the project in full context. 